\title{
Erratum to: Socioeconomic status as a moderator between frailty and mortality at old ages
}

Danan $\mathrm{Gu}^{1 *}$, Fang Yang ${ }^{2}$ and Jessica Sautter ${ }^{3}$

\section{Erratum}

Unfortunately, the original version of this article [1] contained an error within the results section of the abstract. The sentence beginning with "We found that a one percentage point increase" read "....HR $=1.027,95 \%$ CI: $1.025-1.027 \ldots$.. but should have read "...HR $=1.027$, 95 \% CI: 1.025-1.029..." The upper limit of "1.027" was wrong, and was inconsistent with Table 2 . This has been corrected in the original article.

\section{Author details}

'United Nations Population Division, Two UN Plaza, DC2-1910, New York, NY 20012, USA. ${ }^{2}$ Department of Social Work, School of Sociology and Political Science, Shanghai University, Shanghai, China. ${ }^{3}$ Department of Behavioral and Social Sciences, University of the Sciences, Philadelphia, USA.

Received: 19 August 2016 Accepted: 19 August 2016

Published online: 08 September 2016

\section{Reference}

1. Gu D, Yang F, Sautter J. Socioeconomic status as a moderator between

frailty and mortality at old ages. BMC Geriatrics. 2016;16:151. doi:10.1186/ s12877-016-0322-2.

\footnotetext{
*Correspondence: gudanan@yahoo.com

'United Nations Population Division, Two UN Plaza, DC2-1910, New York, NY 20012, USA

Full list of author information is available at the end of the article

Submit your next manuscript to BioMed Central and we will help you at every step:

- We accept pre-submission inquiries

- Our selector tool helps you to find the most relevant journal

- We provide round the clock customer support

- Convenient online submission

- Thorough peer review

- Inclusion in PubMed and all major indexing services

- Maximum visibility for your research

Submit your manuscript at www.biomedcentral.com/submit 